International Journal of Education, Learning and Development

Vol.8, No.1, pp.1-9, January 2020

Published by ECRTD-UK

Print ISSN: 2054-6297(Print), Online ISSN: 2054-6300(Online)

\title{
CULTISM-ASSOCIATED INSECURITY AND THE ACADEMIC ACHIEVEMENT OF THE NIGERIAN STUDENT CROSS RIVER STATE EXPERIENCE
}

\author{
Onete U. Onete (Ph.D) \\ Cross River University of Technology \\ Calabar-Nigeria
}

\begin{abstract}
This study investigated the relationship between cultism-associated insecurity and the academic achievement of the Nigerian students. The study employed the expost-facto research design. Two research hypotheses were formulated to give direction to the study. A total of 748 students sampled from a population of 37,416 senior secondary three (SSIII) students were selected for this study. Cultism-Associated Insecurity and the Learning of the Nigerian Students Questionnaire (CAILNSQ) were administered on the selected respondents for the purpose of data gathering. The instrument has a reliability coefficient of 0.81 . The two hypotheses were tested with the regression and ANOVA statistical techniques at 0.05 significance level. At the end of data analysis it was revealed that there is significant relationship between cultism-induced emotion and academic achievement of the Nigerian secondary school students, and also, cultism-associated insecurity significantly predict the academic achievement of students.Based on the revelations made in this study, it was recommended among others that novelty or carnival days should be introduced and observed occasionally as days of relaxation, fun and enjoyment. Those days will among other things create a placebo effect and diffuse academic tension, bringing staff and students under a common denominator of merry-making to reduce fear of the unknown.
\end{abstract}

KEYWORDS: insecurity, cultism; emotion, academic achievement , student learning

\section{INTRODUCTION}

According to Abraham Maslow's hierarchy of needs security comes in after the physiological needs in order of importance. Human beings can strive to satisfy other higher needs including the need to learn or acquire higher education only if they feel secured. For the attainment of effective teaching and learning, it is important for students and staff to feel safe and secure in the school environment. A situation where an individual in an environment including school environment is not sure of safety of his/her life or property amounts to insecurity in that environment. The school is where the child spends reasonable amount of his/her time, and where he/she explores independence without the intervention of his/her parents. As a result there is a tendency to develop and exhibit behaviours which are never displayed at home. Such behaviours may include 
International Journal of Education, Learning and Development

Vol.8, No.1, pp.1-9, January 2020

Published by ECRTD-UK

Print ISSN: 2054-6297(Print), Online ISSN: 2054-6300(Online)

disrespect to constituted authority or outright disregard to school rules and regulations. Over the years, it has been observed that severe disciplinary problems occur in different levels of Nigerian educational institutions (Onete, Akpama, Egong \& Okey, 2012). Some of the learning institutions have been turned into battle fields where learners bring weapons of various shades, sizes and forms into school, and in most cases used same against themselves as individuals or in groups. This situation poses serious security challenge to the institution experiencing it, disruption of learning activities and students missing classes for fear of being attacked by other students. Insecurity, the bane to the stability and growth of our educational system with devastating effect on learning is the antithesis of security. Belend (2015) defined insecurity as the state of fear and anxiety stemming from concrete or alleged lack of protection. The anxiety experienced when one feels insecure induces negative emotional development which affects behaviour including learning. Emotions exert high influence in guiding and directing learners' behaviour. Many a time students are seen or noted behaving along emotional dictate. However, sometimes, if a learner has no emotional current (an emotion that is sustained throughout some period) in him/her, then, he/she becomes cripple in terms of living his/her life in a normal way (Onete et al., 2012). Thus, emotion such as anxiety or fear plays a vital role in providing a particular direction to learners' behaviour, hence, shaping the personality according to his/her developmental trait (Mangal, 2009). Rockebury and Hockenbury (2007) saw emotion as a complex psychological state that involves three distinct components; a subjective experience, a physiological response and a behavioural response. Emotions are specific reactions to a particular event that are usually of fairly short duration. Emotions are often called feelings which include experiences such as love, hate, anger, trust, joy, panic, fear or anxiety and grief (Mangal, 2009). The concern of this paper is on negative emotions of fear and anxiety.

No doubt, our learning institutions are today faced with the challenge of insecurity, much of which results from the consistent activities of rival cult groups. In Nigeria, according to Denga (1998) cultism has led to the destruction of human, infrastructural and economic resources. He further asserted that cultism has also posed a serious challenge to human and material resources development, including school achievement across the country. In schools where cultist activities prevail, student's graduation is prolonged because of disruption of academic calendar. This means that the business of learning on the part of the Nigerian child is negatively affected. Apparently, cultism promotes calamity of human and development as thousands of students lost their lives and property worth millions of naira are destroyed (Dominic, 2018). Incessant cultists activities in our various institutions of learning in Nigeria have been a cancer that breeds fear, panic and psychological disequilibrium which in turn affects the learning of the Nigerian child resulting in low academic achievement (Denga, 1998). The continuous activities of cultists in nigeria is threatening the unity, peace and love among students in various institutions of learning, paving the way for conflicts of varying degree and magnitude. 
International Journal of Education, Learning and Development

Vol.8, No.1, pp.1-9, January 2020

Published by ECRTD-UK

Print ISSN: 2054-6297(Print), Online ISSN: 2054-6300(Online)

Cultism induces a feeling of insecurity which causes psycho-pathology concerns (fear or anxiety) in educational institutions today (Onete et al., 2012). The activities of these secret cults have sent hundreds of students out of school and to early grave. Unfortunately, these secret cults have spread to the nation's secondary schools. They have signs and symbols that may not make any meaning to outsiders. Their activities have negative effects on both members and non-members as well as the entire school (Umanah, 2018).

Members of secret cults are recruited through application, invitation or by force (Denga, 1998). Some of them are lured into it on the pretext of holding a party especially for new students in undisclosed venues. Such activities are usually nocturnal. The members behave in ways that are not acceptable in the society. They are involved in special rituals in order for them to be initiated and promoted from one level to another, make use of dangerous tools like guns, axes, cutlasses, charms, black juju, daggers, swords among others to carry out their evil activities on their fellow human beings, thereby causing public panic and fear, and sometimes anxiety among learners in the schools environment (Adebayo, 2013).

Cultism causes breakdown of law and order since members who may be students usually disregard their school rules and regulation as well as their teachers who may not be members. Their activities in most cases lead to loss of lives of loved ones like father, mother, brother, sister and other relations as rival cult groups may descend on them if they cannot find the cultists they are in search of. All well-meaning members of the society are against all forms of cultism and their activities as they contradict generally acceptable values and impede on the learning of the Nigerian child.

In the tertiary institutions, the Governing Boards have been given the mandate to expel any student(s) found to belong to a cult group within the school campus. Also, the school authorities of our secondary schools whether public or private are on the watch as any student(s) found to belong to any cult group could be expelled and such person(s) handed over to the police for prosecution in the court of law. More so, responsible parents whose children or wards are known to belong to any cult group are usually not happy and this may sometimes make them to reject or denounce the child. However, these measures seem to yield little or no satisfactory results as learners in most schools continue to learn under emotionally charged school environment occasioned by insecurity arising from cultist activities.

The fundamental problem of cultism is the insecure, unsafe and emotional tension that it brings about across the society including educational institutions thereby leading to poor learning and falling standards in academic achievement. Emotion and learning are closely related. Emotion is a consequence of behaviour while learning is a process that brings about the formation of new behaviours. Though emotion is a consequence of behaviour, it nevertheless influences and gives direction to learning and academic achievement. A fundamental message of the Skinnerian 
Vol.8, No.1, pp.1-9, January 2020

Published by ECRTD-UK

Print ISSN: 2054-6297(Print), Online ISSN: 2054-6300(Online)

psychology is that all organisms are to a great extent influenced by consequences of their own behaviour (Isangedighi in Asagwara, 1994). Isangedighi further opined that any act is naturally followed by an experience which is consequence of the act. Emotion is generated by happenings in the environment, for example, if a student hears a gunshot near his/her classroom block, such encounter if not well managed could induce emotional tension or panic which in turn may affect learning. In most parts of the country including Cross River State the area of study, there are prevailing issues of cultist activities as reported in both the electronic and print media which may have affected the learning effectiveness of the learners. A situation such as this call for some fundamental questions about how cultism associated insecurity affects the academic achievement of the Nigerian child. Therefore, this study seeks to investigate the relationship between cultism associated insecurity and the academic achievement of the Nigerian child. The question then is, how does cultism associated insecurity relate to learning or academic achievement of the Nigerian child?

To answer the above question, the following hypotheses are formulated for testing:

1. Cultism associated insecurity and emotion do not significantly predict academic achievement of the Nigerian child.

2. There is no significant relationship between emotion and academic achievement of the Nigerian student.

The significance of this study lies in the fact that if Nigerians become aware of the devastating effects of emotion of fear or anxiety by-products of insecurity on learners, then every effort would be made by members of the society to ensure that every emotion inducing activity(ies) e.g. cultism are checked and put under control.

\section{METHODOLOGY}

The research design adopted for this study was expost-facto. Expost-facto was considered appropriate for use in this study because variables under study have already occurred, and the researcher has no direct control of the independent variables because they are not manipulable.

The population for the study comprised all senior secondary school (SSIII) students in Cross River State Central Education Zone (CEZ). The population was thirty-seven thousand, four hundred and sixteen (37,416) SSIII students as at 2018/2019 academic year (State Secondary Education Board, 2019). Two basic sampling techniques were adopted, namely, stratified random sampling and simple random sampling respectively. The researcher used stratified random sampling because of the definite subsets in the population. Also, random sampling was used to give each an every student equal and independent chance of being selected. Two percent (2\%) was used to determine 
the sample size of seven hundred and forty eight (748) students from the population of thirty-seven thousand, four hundred and sixteen $(37,416)$ SSIII students.

The instrument used for data collection was researcher designed questionnaire titled "CultismAssociated Insecurity and the Learning of the Nigerian Students Questionnaire (CAILNSQ)". The instrument had a reliability coefficient of 0.81 determined through a test retest correlational method. The instrument was configured on the likert modified rating scale of SA; A; D; and SD.

\section{RESULTS}

Hypothesis 1: Cultism associated insecurity and emotions do not significantly predict academic achievement of the Nigerian child. To test this hypothesis, the data were extracted from the data bank and summarized into mean (X) and standard deviations (SD), as well as sums ( $\left.\sum \mathrm{X} \sum \mathrm{Y}\right)$, sum of squares testing $\left(\sum \mathrm{X}^{2} \sum \mathrm{Y}^{2}\right)$, sum of cross product $\left(\sum X Y\right)$, and subjected to analysis using multiple regression statistics procedure. See results in tables 1,2 and 3.

Table 1: Model summary analysis of relationship of academic achievement due to emotion and cultism associated insecurity. $N=748$

\begin{tabular}{ccccc}
\hline Model & $\mathbf{R}$ & $\mathbf{R}^{\mathbf{2}}$ & Adjusted $\mathbf{R}^{\mathbf{2}}$ & $\begin{array}{c}\text { Standard Error } \\
\text { of Estimate }\end{array}$ \\
\hline 1 & $.908^{\alpha}$ & .825 & .825 & 1.82973 \\
\hline
\end{tabular}

a. Predictors (constant) cultism, insecurity.

Table 1 shows a R-calculated value of $0.908^{\mathrm{a}}, \mathrm{aR}^{2}$-value of 0.825 , and an adjusted $\mathrm{R}^{2}$-value of 0.825 . This means that of the total weight predicting academic achievement, 82.5 percent was asserted to be occasioned by cultism and insecurity emotion among Nigerian students.

Table 2: Model summary of ANOVA for the Regression analysis.

\begin{tabular}{|c|c|c|c|c|c|}
\hline Model & $\begin{array}{l}\text { Sum of Squares } \\
\text { (SS) }\end{array}$ & Df & $\begin{array}{l}\text { Mean Squares } \\
\text { (MS) }\end{array}$ & F-cal & Sign \\
\hline $\begin{array}{l}\text { Regression } \\
\text { Residual } \\
\text { Total }\end{array}$ & $\begin{array}{l}11,781.920 \\
2,494.191 \\
14,276.111\end{array}$ & $\begin{array}{l}2 \\
745 \\
747\end{array}$ & $\begin{array}{l}5890.960 \\
3.348\end{array}$ & 1759.595 & .0000 \\
\hline
\end{tabular}

a. Dep. Var. academic achievement

b. Predictors (constant) cultism and insecurity

From table 2, the result of analysis of variance (ANOVA) statistics for the regression model portrayed F-calculated value of 1759.595 which was found to be far higher than the critical F- 
value of 3.002 needed for significance at 0.05 alpha levels with 2 and 745 degrees of freedom. With this result, the null hypothesis was rejected. This means that cultism associated insecurity significantly predict the academic achievement of the Nigerian students.

To determine the line of "best" for the model, table 3 was developed and presented as follows:

Table 3: Summary of B-coefficient for regression model of the estimate.

\begin{tabular}{cc|cccc}
\hline Model & \multicolumn{2}{c}{ Unstandardized coefficient } & $\begin{array}{c}\text { Standardized } \\
\text { coefficient }\end{array}$ & t-values & Sign. \\
\hline \multicolumn{1}{c|}{ B } & $\begin{array}{c}\text { Std. Error of } \\
\text { Est. }\end{array}$ & Beta & & \\
\hline Constant & .078 & .254 & - & .308 & .758 \\
Insecurity & .0381 & .065 & .374 & $5.840^{*}$ & .000 \\
Emotion & .587 & .070 & .541 & $8.435^{*}$ & .000 \\
\hline
\end{tabular}

a. Dep. Var. Academic achievement

$*$ Result significant at $\mathrm{p}<0.5 ; \mathrm{df}=745$, crit- $\mathrm{t}=1.968$

From table 3, the regression constance of 0.078 was given off, with B-coefficients (or calculated t-value) of $5.840^{*}$ (for insecurity) and $8.435^{*}$ (for cultism induced emotion), these were all greater than the critical t-value of 1.968 needed for significance at 0.05 alpha level with 745 degrees of freedom.

Based on these results, the final regression line of "best fit" for the model was given as:

$Y=K+a x,+b x_{2}$, where $Y=$ Criterion or Dep. Variables, $K=$ Regression constant, $a$ and $b=$ regression coefficient, and $X_{1}$ and $X_{2}=$ predictor factors insecurity and emotion i.e. academic achievement is predicted by 0.078 constance +5.84 insecurity +8.35 cultism induced emotion among Nigerian secondary school students.

Hypothesis 2: There is no significant relationship between cultism induced emotion and academic achievement of the Nigerian student.

To test this hypothesis, data was extracted from the data bank and summarized into sums $\left(\sum X \sum Y\right)$, sum of squares testing $\left(\sum \mathrm{X}^{2} \sum \mathrm{Y}^{2}\right)$, and sums of product $\left(\sum \mathrm{XY}\right)$. The summarized data were subject to analysis using Pearson Product Moment Correlation (r) statistics. The result of the analysis is presented in table 4. 
Print ISSN: 2054-6297(Print), Online ISSN: 2054-6300(Online)

Table 4: Pearson Product Moment Coefficient Analysis of the relationship between cultism induced emotion and academic achievement of SS Students. N=748

\begin{tabular}{l|lcc}
\hline \multicolumn{2}{l}{} & \multicolumn{1}{c}{$\begin{array}{c}\text { Cultism induced } \\
\text { emotion }\end{array}$} & $\begin{array}{c}\text { Academic } \\
\text { achievement }\end{array}$ \\
\hline $\begin{array}{l}\text { Cultism induced } \\
\text { emotion }\end{array}$ & $\begin{array}{l}\text { Pearson correlation } \\
\text { sign. (2-tailed) } \\
\text { Sum of squares and } \\
\text { cross product } \\
\text { Covariance }\end{array}$ & 1 & -.433 \\
& N & 12793979 & .000 \\
& Pearson correlation & $-0.433^{* *}$ & 6170706 \\
Academic & sign. (2-tailed) & .000 & -8261 \\
achievement & Sum of squares and & -6170706 & 748 \\
& cross product & & 15888.956 \\
& Covariance & 748 & \\
& N & 748 & 748 \\
\hline
\end{tabular}

*Correlation significant at $\mathrm{P}<.01$ level (2-tailed).

From table 4, the calculated correlation ( $r$ ) value of -).433* was found to be significant because the p-value of 0.00 associated with the correlation coefficient was found to be lower than 0.05 alpha level with 746 degrees of freedom. With this result the null hypothesis was rejected. This implies that there is significant relationship between cultism induced emotion and the academic achievement of the Nigerian secondary school students.

\section{DISCUSSION}

The statistical analysis of hypothesis one revealed that academic achievement of Nigerian secondary school students is predicted by 0.078 constance, 5.84 insecurity and 8.35 cultism induced emotion. These findings corroborate Adebayo (2013) assertion that cultist activities on our learning institutions today have made so many innocent and serious minded students to become afraid of the unknown since both the guilty and innocent ones are affected during cult clashes of rival groups in schools thus making school environment emotionally charged, insecure and unconducive for learning with its attendant effect on academic underachievement. Again, Denga (1998) has revealed that incessant cultist activities in our various institutions of learning in Nigeria have been a cancer that breeds fear, panic, and psychological disequilibrium which in turn affects negatively the learning of the Nigerian child resulting in low academic attainment. As a matter of common knowledge, it is established that no meaningful teaching and learning can ever take place 
Vol.8, No.1, pp.1-9, January 2020

Published by ECRTD-UK

Print ISSN: 2054-6297(Print), Online ISSN: 2054-6300(Online)

in an atmosphere of insecurity and when this happens, the end result is low academic productivity on the part of the students.

Similarly, the statistical analysis of hypothesis two showed that there is a significant relationship between cultism induced emotion and the academic achievement of Nigerian students. This revelation is in congruent with Denga (1998) who observed that cultism generates or induces negative emotions like fear and anxiety which pose serious challenge to human and material resources development including poor school enrolment, school attendance and academic achievement. In the same vein, Onete et al. (2012) have asserted that cultist activities remain one emotion induced psychopathological challenge confronting Nigerian learning institutions today, and that these activities especially when they come in form of violent clashes have sent hundreds of students out of school and in most cases to early grave. It is for this reason that cultist activities are dreaded with morbid fears and anxiety, and so no serious academic work is likely to take place in an atmosphere of fight and insecurity.

\section{CONCLUSION}

It is evident from the beginning of this paper that cultism associated insecurity has permeated and adversely affected the operations in our school system, resulting in poor/low academic outcomes. If the level of cultist activities in Nigerian schools today is not scaled down or appropriate measures not taken to eradicate it completely, then Cross River State will continue to be listed as educationally disadvantaged state. This will impede manpower development of drive the current administration of Governor Ben Ayade in the state.

\section{Recommendations}

On account of the findings of this study the following recommendations were volunteered:

- Sporting activities should be organized at appropriate times but brief not to disrupt time and school calendar, but to divert students attention from behaviour that can cause panic, fear or emotion on other students. This could also be a vehicle for youths to vent out the vast energies bottled up in them through engaging in acceptable satisfactory and rewarding activities.

- The security department of secondary schools should be armed with plastic bullets enough to blast cultists. The use of fire arms should be partially legitimized to make the internal security effective.

- Effective security in schools; school administrations should ensure they provide effective security measures in school environments to protect students from harassment and intimidation from others, when this happens students will not feel the need to seek protection by forming or joining cult groups. 
International Journal of Education, Learning and Development

Vol.8, No.1, pp.1-9, January 2020

Published by ECRTD-UK

Print ISSN: 2054-6297(Print), Online ISSN: 2054-6300(Online)

- Encouragement of academic excellence by all in the society by providing conducive learning environment for students as well as supporting activities that encourage effective and meaningful learning, this will make students focus more on their education and be less distracted by other things like cultism and drug abuse.

- Novelty or carnival days should be introduced and observed occasionally as days of relaxation, fun or enjoyment. These days will among other things create a placebo effect and diffuse academic tension, bringing staff and students under a common denominator of merry-making to reduce fear of the unknown.

- Government at all levels should seriously confront cultism. The details should according to Denga (1998) include adequate funding so that facilities such as police posts and even police stations can be erected near schools for prompt dispatch of armed police to campuses when cult eruptions are reported, occasional surveillance of school premises to warn members of secret cults about the presence of armed police is equally herein recommended.

\section{REFERENCES}

Adebayo, R.(2013). Indiscipline in Nigerian secondary schools; Types, causes and possible solutions. African Journal of Education and Technology 2(1), 39-47.

Asagwara, C.G. (1994). Applied Psychology in Education. Calabar BON Universal limited.

Belend,(2015). The political construction of collective insecurity: From moral panic to blame avoidance and organized irresponsibility, Centre for European Studies Working Papers Series 126. Lagos, Nigeria.

Denga, D.I. \& Denga, H.M.(1998). Educational malpractice and cultism in Nigeria. Calabar: Rapid Educational Publishers.

Dominic, J.(2018). Cultists on rampage in Bayelsa. TNN March 5, 2018 pg3.

Igbuzor, O.(2011). Peace and security Education: A critical factor for sustainable peace and national development. Journal of Peace and Development Studies, 2, 59-71.

Mangal, S.K.(2009). Advanced educational Psychology (2 ${ }^{\text {nd }} e d$ ). New Delhi; Rajkamal Electric Press.

Olabanji, O. E. \& Ese, U. (2014). Insecurity and socio-economic development in Nigeria. Journal of Sustainable Development Studies 5(1), 40-63.

Onete, O. U.; Akpama, E.G; Egong A. I. \& Okey, S. A. (2012). Cultism: As a socially related cause of violence among students in tertiary institutions in Cross River State, Nigeria. Counselling implications. Journal of the Nigerian Society for Educational Psychologists, 10 (1), 155-161.

Rockebury, H. \& Hockenbury, A. (2007). Emotions and leadership: The role of emotional intelligence. Human Relations 53 (8), 1027-1055.

Umanah, O. (2018) Militants overwhelmed Udom, sack schools in Akwa Ibom villages. TNN March 19,2018 pp 5 \& 8. 